\title{
The Effect of Share Ownership Concentration and Company Operation Complexity towards Transfer Pricing Decisions
}

\author{
Siska Liana \\ Faculty of Economics and Business \\ Universitas Padjadjaran \\ Sugiono Poulus \\ Faculty of Economics and Business \\ Universitas Padjadjaran \\ Arie Pratama \\ Faculty of Economics and Business \\ Universitas Padjadjaran
}

\begin{abstract}
This research aims to examine the effect of share ownership concentration and company operation complexity on transfer pricing decisions. The transfer pricing decision in this research is measured by the total indicators of related party transactions of the company. The population in this research are all companies listed on the Indonesia Stock Exchange from 2017 to 2018. The sample selection technique used is purposive sampling, and hence, 116 companies have been obtained. The data used in this research were obtained from financial statement data. The data analysis method used in the research is the multiple linear regression analysis. The results showed that share ownership concentration did not affect transfer pricing decisions, whereas company operation complexity projected by multinationality had a significant positive effect on transfer pricing decisions. Research shows that multinational companies are considered to have more significant opportunities by taking advantage of the differences in tax rates.
\end{abstract}

Keywords: Share Ownership Concentration; Multinationality; Transfer Pricing Decisions; Tax rates

\section{Introduction}

Special relationship transaction is a serious problem for tax authorities in various countries, particularly in Indonesia. This problem arises due to the company's policy in determining the transfer price, where they use unreasonable transfer prices in the transaction. The nature of affiliate transactions is an ordinary matter and is not legally prohibited (Mury, 2015: 195). Transfer pricing practices are formerly used to assess performance among company members or divisions, but as time goes by, transfer pricing is used to maximize profits and conduct tax management by minimizing the amount of tax that must be paid by the companies (Mangoting, 2000).

Transfer pricing is a sensitive issue in the business world and the global economy, mainly in the taxation sector. The activity of transfer pricing carried out by multinational companies may affect the level of state revenue from the tax side by utilizing existing regulatory gaps by transferring profits to countries with lower tax rates. Globalization makes economic development in the world more rapid without boundaries to increase international transactions or cross border transactions (Rezky \& Fachrizal, 2018). The practice of transfer pricing does not only involve goods, but other movable assets are also capital which causes international trade transactions with multinational companies in one group to grow even more complicated. Different tax rates in each country are one of the triggers for complexity in analyzing and understanding the transaction. It can be an opportunity, especially for multinational 
companies, to make tax savings by transfer pricing practices.

In the case of transfer pricing, the tax authority must have strong reasons that the parties have carried out transfer pricing for tax evasion. Before proving the transfer pricing, it must be proven first that the parties are involved in an affiliation. Many companies in Indonesia are affiliated with company groups. Affiliate relationships can occur for several reasons, one of which is when the shareholders contrive to maximize the return of their entire investments by instructing the company to conduct transactions with related parties, and these activities generate favorable results for a party and unfavorable ones to the other (Pratama, 2017). According to Law No. 36/2008, special relationships among taxpayers can occur due to dependency or bond to one another due to ownership, equity inclusion, or domination through management or use of technology.

Table 1. Tax Revenues in the Period of 2008-2018

\begin{tabular}{cccc}
\hline \multirow{2}{*}{ Period } & \multicolumn{3}{c}{ Taxation Sector } \\
\cline { 2 - 4 } & $\begin{array}{c}\text { Target } \\
\text { (in Trillion) }\end{array}$ & $\begin{array}{c}\text { Achieved } \\
\text { (in Trillion) }\end{array}$ & $\begin{array}{c}\text { Percentage } \\
(\%)\end{array}$ \\
\hline 2009 & 577 & 545 & 94,4 \\
2010 & 662 & 628 & 94,8 \\
2011 & 879 & 874 & 99.4 \\
2012 & 1016 & 980 & 96.4 \\
2013 & 1148 & 1077 & 93.8 \\
2014 & 1246 & 1146 & 91.9 \\
2015 & 1700 & 1524 & 89,6 \\
2016 & 1539 & 1283 & 83,4 \\
2017 & 1283 & 1147 & 89,4 \\
2018 & 1471 & 1339 & 91,0 \\
\hline
\end{tabular}

Tax revenue targeted by the government in the past ten years has not reached its target. One reason is the increase in tax dispute cases. Based on the records of the Tax Court in 2017, the number of tax dispute files according to the appellee and defendants stepping into the tax court is 7,648 cases. This number is higher when it is compared to the previous year in 2016 and 2015 by 7,080 and 7,454 cases, respectively. Efforts on sealing the crack to reduce tax disputes must be conducted continuously by the government, one of which is by strengthening the process of monitoring the disputes that originate from transfer pricing determination (Suwiknyo, 2018).

In 2016, the Directorate General of Taxes stated that 2000 multinational companies were operating in Indonesia carrying out transfer pricing practices. For ten years, the company did not pay corporate income tax on the grounds of loss. The mode used by multinational companies to avoid their obligations to pay taxes in Indonesia include: first, the company has a holding company abroad and has an affiliate relationship, the existence of royalty payments paid from the subsidiary to the holding company is prone to the occurrence of transfer pricing practices; second, there are tax incentives such as tax holidays when filings are made to the Investment Coordinating Board, where many multinational companies raise costs for the purchase of capital goods; and the third, by frequently changing company names. The aim is that the company is reported to experience a further loss; therefore, they may again obtain the tax incentives. It is proven where the realization of tax revenues in 2016 decreased by 241 trillion (Ariyanti, 2016).

The share ownership concentration influences the company's decision to conduct transfer pricing. In Indonesia, the structure of 
share ownership tends to be concentrated and unscattered (Classens et al., 2000), this can trigger clashes between majority and minority shareholders. Where majority shareholders have the right to control the entire company policies, without regard to minority share interests. There are several studies on the effect of share ownership concentration on transfer pricing decisions. Lo et al. (2010) stated that the government in China is the majority shareholder who conducted tax savings at the expense of minority shares and transferring them to the holding company. It proves the influence of share ownership concentration on the transfer pricing decision.

Another factor that affects the practice of transfer pricing is company operation complexity related to the business combination carried out by two or more companies (Suwardjono, 2014). With a business combination, when one company loses money, another company may still make a profit as it should. So the risk may be smaller, and the overall profit is stable. The dissimilarity of tax rates in each country is one of the triggers for complexity in analyzing and understanding the transaction. It can be an opportunity, especially for multinational companies, to make tax savings through transfer pricing practices. This practice is often carried out by multinational companies whose activities operate in more than one country. Richardson et al. (2013) stated that multinationality has a significant effect on transfer pricing decisions. Multinational companies have a stronger impulse in transfer pricing to avoid taxes by utilizing different tax policies between countries.

This research aims to determine the effect of share ownership concentration and company operation complexity projected by multinationality on the transfer pricing decision. This research is a replication of a study by Richardson et al. (2013). The transfer pricing indicator used in this research is modified by adjusting the current conditions of Indonesia. The transfer pricing indicator in this research is the total related party transactions, whereas previous studies only revealed the presence or absence of related party transactions. It can indicate the level of significance of each transfer pricing indicator.

\section{Literature Review}

\section{Agency Theory}

Agency theory that explains the relationship between corporate managers (agents) and shareholders (principals) was firstly stated by Jensen and Meckling (1976). In agency theory, what is meant by an agent is management that manages the owner's assets, while the principal is a shareholder. In general, an agency relationship may not be separated from agency problems or agency conflicts. This conflict is based on personal interests (self-interest behavior) that can occur between management and shareholders. Conflicts that occur between shareholders and managers are called type 1 agency conflicts. Panda and Leepsa (2017) stated that type 1 agency conflicts arise due to the fulfillment of personal satisfaction based on the rationality of human behavior. Whereas the ownership structure is concentrated in companies creating type 2 agency conflict. Villalonga and Amit (2006) stated that type 2 agency conflict occurs between majority and minority shareholders. Majority shareholders can use the amount of their ownership to control minority shareholders for personal gain, thereby causing minority shareholders to suffer losses (Famma \& Jensen, 1983).

\section{Transfer Pricing}

Transfer pricing is an inter-company policy that is influenced by a special relationship in determining the transfer price of a transaction (Mury, 2015: 195). The Organization for Economic Co-operation and Development (OECD) defined transfer pricing as the transfer price of a transaction determined in a group that has an affiliated relationship that deviates from its fair price. The Ministry of Finance Indonesia issued Regulation No.213/PMK.03/2016 in order to establish new provisions concerning transfer pricing documents. This regulation includes provisions on the reporting of master documents, local documents, and reports per taxpayers (state) conducting special relationship transactions.

\section{Share Ownership Concentration}

The transfer pricing decision is affected by the share ownership concentration. The 
concentration of share ownership describes who and how to control the majority of the company's business activities (Abdullah, 2008). La Porta (1999), through the pyramid structure of high control rights, controlling shareholders have greater power over their cash flow rights. Through the transfer pricing mechanism, controlling shareholders can have a particular impact on the management policies, and they can even relish the tax benefits themselves. Therefore, controlling shareholders can conduct expropriation, namely by regulating company transactions and transferring tax benefits to other companies owned by controlling shareholders without regard to the interests of noncontrolling shareholders.

\section{Company Operation Complexity}

The complexity of the company's operations depends on the location and number of operating units (branches) and diversification of product lines and markets. The number of subsidiaries owned can cause the complexity of the company's operations to become more complicated. One way for companies to increase their profits is to expand their business. The complexity of this study uses indicators of multinationality. Multinational companies are companies that have at least one subsidiary outside their country. This subsidiary is wholly owned by the holding company to maximize the value of the multinational company as a whole (Pithaloka and Irwanto, 2016). In this research, the indicators used in measuring multinationality are the number of foreign subsidiaries compared to the number of subsidiaries.

\section{The Effect Of Share Ownership Concentration On Transfer Pricing Decisions}

Zhou (2011), in his research in China, stated that most of the companies in China are sole and concentrated shareholders and have a strong relationship with their government. Thus, the higher the concentration of share ownership, the higher the proportion of control. It shows a positive relationship between controlling shareholders and the practice of transfer pricing. Timothy (2010) states that the higher the percentage of shareholders, the more significant the proportion of company policy and has a more significant influence so that it can be confident that the policy can benefit shareholders controlling and choosing aggressive tax policies through the practice of transfer pricing.

Hypothesis 1: Share ownership concentration affects the transfer pricing decision.

The Effect Of Share Ownership Concentration Projected With Multinationality On Transfer Pricing Decisions

Chandraningrum (2014) claimed that multinational companies have the flexibility to take advantage of differences between national tax jurisdictions to make maximum profit sharing. Rizky and Fachrizal (2018) stated that multinationality affects transfer pricing decisions. It proves that multinational companies play a role in transfer pricing decisions. The results of this study are in line with research conducted by Richardson et al. (2013), which states that multinationality has a significant effect on transfer pricing decisions by utilizing differences in tax policies between countries so that multinational companies can be said to have more significant opportunities.

Hypothesis 2: Company operation complexity projected by multinationality affects the transfer pricing decision.

\section{The method, Data, and Analysis}

This type of research used in this research is explanatory research with a quantitative approach. According to Zulganef (2013: 23), explanatory research is research that aims to examine causality between variables that explain a particular phenomenon. In this study, a causal relationship between share ownership concentration and company operation complexity is projected with multinationality with an indication of transfer pricing.

Sampling is conducted by purposive sampling, namely a sampling technique with certain considerations. The criteria used as research samples are (1) Companies listed on the Indonesia Stock Exchange between 2017 and 2018; (2) Companies with no foreign subsidiaries between 2017 and 2018; (3) Companies included in the subsector of banks, insurance, and financial institutions between 
2017 and 2018; (4) Companies with no foreign subsidiaries overseas between 2017-2018; (5)
Companies with no related parties between 2017-2018

Table 2. Samples

\begin{tabular}{|c|c|c|c|}
\hline No & Criteria & $\begin{array}{l}\text { Number of } \\
\text { Companies }\end{array}$ & $\begin{array}{c}\text { Number of } \\
\text { Companies } \\
\text { Observed }\end{array}$ \\
\hline 1 & $\begin{array}{l}\text { Companies listed on the Indonesia Stock Exchange } \\
\text { between } 2017 \text { and } 2018\end{array}$ & 594 & 594 \\
\hline 2 & $\begin{array}{l}\text { Companies included in the subsector of banks, } \\
\text { insurance, and financial institutions }\end{array}$ & (84) & 510 \\
\hline 3 & Companies with no foreign subsidiaries overseas & (438) & 72 \\
\hline 4 & Companies with no related party transaction & (7) & 7 \\
\hline \multirow[t]{2}{*}{5} & Companies identified as outlier & (7) & 7 \\
\hline & Total sample used & & 57 \\
\hline
\end{tabular}

\section{Operationalization of Research Variables}

Table 3. Operationalization of Research Variables
The variables and scales used in this research are presented in the table below:

\begin{tabular}{llll}
\hline \multicolumn{1}{c}{ Variable } & \multicolumn{1}{c}{ Definition } & Dimension & \multicolumn{1}{c}{ Indicator } \\
\hline $\begin{array}{l}\text { Share ownership } \\
\text { concentration }\end{array}$ & $\begin{array}{l}\text { Share ownership } \\
\text { concentration describes } \\
\text { who and how to control the } \\
\text { majority of the company's } \\
\text { business activities }\end{array}$ & $\begin{array}{l}\text { Largest share } \\
\text { ownership }\end{array}$ & $\begin{array}{l}\text { The number of most } \\
\text { significant share ownership } \\
\text { divided by the number of } \\
\text { outstanding shares }\end{array}$ \\
$\begin{array}{l}\text { Company } \\
\text { operation } \\
\text { complexity }\end{array}$ & $\begin{array}{l}\text { Company operation } \\
\text { complexity relates to } \\
\text { corporate units that } \\
\text { cooperate and affect one } \\
\text { another to achieve the } \\
\text { company objective }\end{array}$ & Multinationality & $\begin{array}{l}\text { The number of foreign } \\
\text { subsidiaries divided by the } \\
\text { number of subsidiaries }\end{array}$ \\
& $\begin{array}{l}\text { The policy of a company } \\
\text { that is influenced by a } \\
\text { special relationship in } \\
\text { determining the transfer } \\
\text { price transaction }\end{array}$ & Related party \\
transaction & $\begin{array}{l}\text { The total frequency of } \\
\text { sales transactions, purchase } \\
\text { transactions, interest-free } \\
\text { loan transactions, write-off } \\
\text { transactions, service } \\
\text { transactions, intangible } \\
\text { transactions, and low- } \\
\text { income tax rate } \\
\text { transactions between } \\
\text { related parties. }\end{array}$ \\
\hline
\end{tabular}

\section{Data Collection Technique}

In this research, data is collected through the company's financial statements and annual reports available on the IDX website. Several secondary data sources are taken from statistical bulletins, government publications, information published in the internal or external part of the company, data available from previous research, case studies, company documents, online data, and websites. 


\section{Data Analysis}

The statistical method used in this research is the multiple linear regression analysis. Multiple linear regression analysis analyzes the relationship between one dependent variable with several independent variables. Analysis of financial data with descriptive analysis is conducted by describing or explaining the data that has been obtained without the intention of making generally accepted assumptions or generalizations. Descriptive statistics are associated with the collection and presentation of data; therefore, the data quality can be estimated in the form of variable types, summary statistics (mean, mode, median, and standard deviation), distribution, and pictorial representation

\section{Result and Discussion}

Control exists when the power exceeds half the voting rights in accordance with agreements with other investors with its main characteristics. From a total of 116 sample companies that were studied on the Indonesia Stock Exchange in the period of 2017-2018, there were 56 companies $(48.3 \%)$ with a share ownership concentration above $50 \%$ and 60 other companies $(51.7 \%)$ with a share ownership concentration below 50\%. In Indonesia, the structure of share ownership tends to be concentrated and unscattered, and this may then trigger collisions among the majority and the minority shareholders. In this study, most of the samples had their concentrations below 50\%, and this shows that the concentration of shares tends to spread to companies listed on the Indonesia Stock Exchange in 2017 and 2018.

Table 4. The Largest Number of Foreign Subsidiaries Between 2017 and 2018

\begin{tabular}{lll}
\hline Country & $\mathbf{2 0 1 7}$ & $\mathbf{2 0 1 8}$ \\
\hline Singapore & 108 & 108 \\
Malaysia & 34 & 35 \\
British Island & 16 & 15 \\
Netherlands & 14 & 15 \\
Mauritius & 10 & 11 \\
Vietnam & 10 & 12 \\
\hline
\end{tabular}

From Table 4 above, it can be seen that the majority of the subsidiaries between the period of 2017 and 2018 are found in tax haven countries, namely Singapore, British Island, the Netherlands, and Mauritius, where the tax rates in the country are below the Indonesian tax rates. It shows that companies exploit the differences in tax policies between countries to maximize profits so that multinational companies can be said to have more significant opportunities. The existence of tax havens countries supports multinational companies to conduct transfer pricing practices.

\section{Multiple Linear Regression Analysis}

From the data obtained on the Indonesia Stock Exchange between 2017 and 2018, items related to the transfer pricing indicator in 2017 are as follow: the total frequency of sales transactions have amounted to 225 transactions, the total frequency of purchase transactions have amounted to 144 transactions, the total frequency of service transactions have amounted to 75 transactions, the total frequency of transactions related to intangible assets have amounted to 4 transactions, the total frequency of transactions related to non-interest loans are 56 transactions, and the total frequency of transaction related to write-off receivables is 1 transaction.

According to the 2017 estimates, there were 67 foreign related parties transactions with an Indonesian income tax rate of 25 percent. In 2018, there were 201 total sales transaction frequencies, 143 total purchase transaction frequencies, 70 total service 
transaction frequencies, 4 intangible asset related transactions total, 64 total non-interest related loan transactions, and total write-off transaction frequency to as many as 1 transactions. From the 2018 data, there were
68 foreign related parties transactions with an Indonesian income tax rate of 25 percent. The results of the research carried out are as follows:

Table 5. Multiple Linear Regression Equation

\begin{tabular}{|c|c|c|c|c|c|c|}
\hline \multirow{2}{*}{\multicolumn{2}{|c|}{ Model }} & \multicolumn{2}{|c|}{$\begin{array}{l}\text { Unstandardized } \\
\text { Coefficients }\end{array}$} & \multirow{2}{*}{\begin{tabular}{|c|}
$\begin{array}{c}\text { Standardized } \\
\text { Coefficients }\end{array}$ \\
Beta \\
\end{tabular}} & \multirow[b]{2}{*}{$\mathrm{T}$} & \multirow[b]{2}{*}{ Sig. } \\
\hline & & B & $\begin{array}{l}\text { Std. } \\
\text { Error }\end{array}$ & & & \\
\hline \multicolumn{2}{|r|}{\begin{tabular}{l|l}
1 & (Constant)
\end{tabular}} & 1.907 & .221 & & 8.632 & .000 \\
\hline \multirow{2}{*}{\multicolumn{2}{|c|}{\begin{tabular}{|c|}
$\begin{array}{c}\text { Share Ownership } \\
\text { Concentration }\end{array}$ \\
Multinationality
\end{tabular}}} & -.717 & .380 & -.170 & -1.888 & .062 \\
\hline & & .828 & .320 & .233 & 2.588 & .011 \\
\hline
\end{tabular}

From Table 8 above, the following equation is obtained: $\quad Y=1.907-0.717 X_{1}+0.828 X_{2}$. The results of the multiple linear regression equation can be interpreted as follows: The constant value of 1.907 states that if the two independent variables namely Share Ownership Concentration and Company Operation Complexity that are projected with Multinationality are 0 (zero), and there is no change, then the Transfer Pricing Decision is worth 1,907. The value of the Company Operation Complexity projected with Multinationality has a regression coefficient of 0.828 meaning that if the Company Operation Complexity projected by Multinationality increases by one percent, while other variables are constant, then the Transfer Pricing Decision may increase by 0.828 .

\section{F-statistic Test}

Based on the statistical results, an F-count of 5.007 with a significance (p) of 0.008 is obtained. For a significance level of 0.05 with degrees of freedom $\mathrm{dk} 1=2$, and $\mathrm{dk} 2=116-2$ $1=113$, Ftable $=3.077$ are obtained. Based on the results, therefore F-count $=5.007>$ Ftable $=3.077$, and the significance $(p)$ of $0.008<$ 0.05 , according to the criteria Ho is rejected and $\mathrm{Ha}$ is accepted. Thus it can be concluded that Share Ownership Concentration and Company Operation Complexity projected by Multinationality simultaneously affects the Transfer Pricing Decision.

\section{Coefficient of Determination Test}

The coefficient of determination is used to observe the magnitude of the simultaneous effect of Share Ownership Concentration and Company Operation Complexity projected by Multinationality to the Transfer Pricing Decision.

Table 6. Coefficient of Determination Test between Variables

\begin{tabular}{|l|l|l|l|c|}
\hline Model & $\mathrm{R}$ & $\mathrm{R}$ Square & Adjusted R Square & Std. Error of the Estimate \\
\hline 1 & $.285 \mathrm{a}$ & .081 & .065 & .81659289 \\
\hline \multicolumn{2}{|l|}{ a. Predictors: (Constant), Multinationality, Share Ownership Concentration } \\
\hline \multicolumn{2}{|l}{ b. Dependent Variable: Transfer Pricing } \\
\hline
\end{tabular}

Table 6 shows the value of $\mathrm{R}$ Square or the coefficient of determination of 0.065 or
$6.5 \%$. These results indicate that the Share Ownership Concentration and Company 
Operation Complexity projected by Multinationality simultaneously affects $6.5 \%$ of the Transfer Pricing Decisions, while the remaining amount of $93.5 \%$ is influenced by other variables that are not examined in this study.

\section{The Effect of Share Ownership Concentration on Transfer Pricing Decisions}

From the results on the effect of Share Ownership Concentration on the Transfer Pricing Decision, the result of $\mathrm{t}$-count $=1,888$ $<$ ttable 1,981 , and the significance $(\alpha)$ is 0.078 $>0.05$, according to the criteria, Ho is accepted and $\mathrm{Ha}$ is rejected. Thus it can be concluded that the Share Ownership Concentration does not affect the Transfer Pricing Decision. The Share Ownership Concentration is proxied by the most significant number of shares divided by the number of outstanding shares, which indicates that the controlling shareholder does not affect management in making transfer pricing decisions. In Indonesia, the share ownership structure tends to be concentrated and unscattered (Classens et al., 2000), it can trigger clashes between majority and minority shareholders. Where majority shareholders have the right to control the entire company policies, without regard to minority share interests.

According to Indonesia Financial Accounting Standards (initially referred to as Pernyataan Standar Akuntansi Keuangan or abbreviated as PSAK) 65, an investor controls an investee when the investor is exposed or has the right to variable return from his/her involvement with the investee and can affect the returns through his/her authority upon the investee (controlling interest). Control exists when power exceeds half the voting rights in accordance with agreements with other investors with its main characteristics. From a total of 116 sample companies that were examined on the Indonesia Stock Exchange between the period of 2017 and 2018, there were 56 companies (48.3\%) with a stock concentration above $50 \%$ and 60 other companies $(51.7 \%)$ with a concentration of share ownership below $50 \%$. The results of this study contradict the hypothesis described earlier. However, this research was supported by previous research by Khotimah (2018).
The Effect of Company Operation Complexity Projected By Multinationality on Transfer Pricing Decisions

From the results on the effects of Share Ownership Concentration projected with Multinationality, the following result is obtained t-count $=2.588>\mathrm{t}$-table $=1.981$, and the significance $(\alpha)$ of $0.011<0.05$, according to the criteria, $\mathrm{Ho}$ is rejected and $\mathrm{Ha}$ is accepted. Thus it can be concluded that the Company Operation Complexity projected by Multinationality affects the Transfer Pricing Decision. Rezky and Fachrizal (2018) stated that multinationality affects transfer pricing decisions. It proves that multinational companies play a role in transfer pricing decisions. The results of this study are in line with research conducted by Richardson et al. (2013), which stated that multinationality has a significant effect on transfer pricing decisions by utilizing differences in tax policies between countries so that multinational companies can be said to have more significant opportunities.

\section{Conclusion}

Based on the results of multiple linear regression analysis, it can be concluded that the concentration of share ownership does not affect the transfer pricing decision. These results indicate that the size of share ownership concentration did not affect the company's consideration for transfer pricing practices. Whereas, company operation complexity projected by multinationality has a positive effect on transfer pricing decisions. These results indicate that the higher the complexity of the company's operations (projected by multinationality) may increase the decision of the company to conduct transfer pricing.

Based on the results of the analysis and conclusions, the researcher suggests that future studies can consider other variables to develop factors that affect Transfer Pricing decisions and may also consider increasing the number of study samples and covering more extended research periods. Companies should be able to reveal a more precise disclosure of tax-related financial information so that publicly available reports are transparent, and therefore, no one can misuse the transfer pricing transactions that cause losses to the country. For the 
Government, the results of this research are expected to be taken into consideration in making tax regulations to reduce the transfer pricing actions undertaken by the company. The tax authorities should be able to increase supervision and monitoring the implementation of corporate tax obligations.

\section{References}

Abdullah, W.Z.W. 2008. The Impact of Board Composition, Ownership and CEO Duality on Audit Quality: The Malaysian Evidence, Malaysian Accounting Review, Vo.7, No.2, pp.1728

Ariyanti, Fiki, 2000 Perusahaan Asing Gelapkan Pajak Selama 10 Tahun (2000 Foreign Companies Divert Tax for 10 Years). Retrieved from https://www.liputan6.com/bisnis/read/2 469089/2000-perusahaan-asinggelapkan-pajak-selama-10-tahun

Barford, Vanessa. 2013. Google, Amazon, Starbucks: The Rise of Tax Shaming. Retrieved from https://www.bbc.com/news/magazine20560359

Chandraningrum, T. M. 2014. Pengaruh Transfer Pricing Terhadap Perencanaan Pajak Bagi Perusahaan Multinasional (The Effect of Transfer Pricing on Tax Planning for Multinational Companies), Jurnal Akuntansi UNESA (Journal of Accountancy, UNESA)

Claessens, S., Djankov, S., \& Lang, L.H.P. 2000. The separation of ownership and control in East Asian Corporations, Journal of Financial Economics, Vol.58, No. 1-2, Pp. 81-112, https://doi.org/10.1016/S0304405X(00)00067-2

Famma, E.F. \& M.C. Jensen. 1983. Separation of Ownership and Control, Journal of Law and Economics, Vol.26, Page $301-$ 325
Jensen, M.C. \& W.H. Meckling. 1976. Theory of the Firm: Managerial Behavior, Agency Costs and Ownership Structure, Journal of Financial Economics 3, 305$360, \quad$ https://doi.org/10.1016/0304405X(76)90026-X

La Porta, Rafael, Florencio Lopez-de-Silanes, Andrei Shleifer. 1999. Corporate Ownership Around The World, Journal of Finance, Vol. 54, pp. 471-517

Lo, W. Y. A., Raymond. M.K. W., \& Micheal F. 2010. Tax, Financial Reporting, and Tunneling Incentives for Income Shifting: An Empirical Analysis of the Transfer Pricing Behavior of ChineseListed Companies, Journal of the American Taxation Association, Vol. 32, No. 2: 1-26, https://doi.org/10.2308/jata.2010.32.2.1

Mangoting, Yenni. 2000. Tax Planning: Sebuah Pengantar Sebagai Alternatif Meminimalkan Pajak (Tax Planning: An Introduction as an Altenative to Minimize Tax), Jurnal Akuntansi dan Keuangan (Journal of Accounting and Finance), May, Vol.1, No.1

Khotimah, Siti.2018. Pengaruh Beban Pajak, Tunneling Incentive, dan Ukuran perusahaan Terhadap Keputusan Perusahaan Dalam Melakukan Transfer Pricing (The Effect of Tax Expense, Tunneling Incentive, and Company Size on Transfer Pricing Decision). Jurnal Ekobis Dewantara (Journal of Economics and Business Dewantara), Vol. 1, No. 12

Mury, Kurniawan. 2015. Pajak Internasional Edisi Kedua (International Tax Second Edition). Jakarta: Ghalia Indonesia

Panda B, Leepsa N. M., 2017. Agency theory: Review of Theory and Evidence on Problems and Perspectives, Indian Journal of Corporate Governance, 10(1), 74-95, https://doi.org/10.1177/2F09746862177 01467

Phitaloka \& Irwanto. 2016. Pengaruh Status Perusahaan (Multinasional/Domestik) 
dan Degree of Internationalization terhadap Firm Perfomance (The Effect of Company Status (Multinational/Domestic Company) and Degree of Internationalization on Firm Performance), Jurnal Ekonomi dan Bisnis (Journal of Economic and Business), Vol 2 No Agustus 2016.

Pratama, A. (2017). Does Corporate Governance Affect Related-Party Transactions? A Study on Indonesian Companies Listed on the Indonesian Stock Exchange in 2011-2015. Proceedings of Society of Interdisciplinary Business Research (SIBR) Kuala Lumpur, February 2017

Rezky, Machfirah \& Fachrizal. 2018.Pengaruh Mekanisme Bonus, Ukuran Perusahaan, Leverage dan Multinationality terhadap Keputusan Transfer Pricing pada Perusahaan Manufaktur yang terdaftar di Bursa Efek Indonesia Tahun 20102014. Jurnal Ilmiah Mahasiswa Ekonomi Akuntansi (Scientific Journal of Accounting Economics Students), Vol 3, No 3, pp. 401-415.

Richardson, Grant \& Taylor, Grantley and Lanis, Roman, 2013, Determinants of Transfer Pricing Agressiveness:Empirical Evidence From Australian Firms, Journal of Contemporary Accounting and Economics, 9 (2): pp. 136-150, https://doi.org/10.1016/j.jcae.2013.06.0 02

Suwardjono. 2014. Teori Akuntansi Perekayasaan Pelaporan Keuangan (Accounting Theory of Financial Reporting Engineering). Yogyakarta: BPFE

Suwiknyo, Edi, Celah Sengketa Pajak Mulai Ditutup (Tax Dispute Gap Began To Be Closed Down). Retrieved from: https://kalimantan.bisnis.com/read/2018 0313/433/748948/transfer-pricingcelah-sengketa-pajak-mulaiditutuphttps://www.kemenkeu.go.id/apb n
Timothy, Yeung Chi Kwan. 2010. Effects of Corporate Governance on Tax Aggressiveness, Hongkong Baptist University.

Villalonga, B., \& Amit, R. (2006). How Do Family Ownership, Management, and Control Affect Firm Value?, Journal of Financial Economics, 80, 385-413. https://doi.org/10.1016/j.jfineco.2004.12 .005

Zhou, Y. 2011. Ownership Structure, Board Characteristics, and Tax Aggressiveness. Lingnan University. http://dx.doi.org/10.14793/acct_etd.3

Zulganef, 2013. Metode Penelitian Sosial dan Bisnis: Cetakan Pertama (Social and Business Research Methods: First Edition), Yogyakarta: Graha Ilmu 